\title{
ORGANIZING ACTIVITIES FOR CHILDREN IN THE ORIENTATION OF STEAM EDUCATION
}

\author{
Nguyen Thi Ut Sau ${ }^{*}$, Le Thi Thuong Thuong ${ }^{2}$ \\ ${ }^{1,2}$ Faculty of Psychology and Pedagogy, Thai Nguyen University of Education. Thai Nguyen city, Vietnam \\ *Corresponding Author: sauntu@tnue.edu.vn
}

Article History: Received: 11 January 2021; Accepted: 27 February 2021; Published online: 5 April 2021

\begin{abstract}
The content of the article analyzes the advantages of STEAM education in the implementation of the kindergarten program in the current period and introduces the plan and results of activities for preschool children according to the STEAM orientation at the school at "May 19" Kindergarten - Thai Nguyen City - Thai Nguyen Province. On the basis of theoretical analysis and current situation, the author proposes a number of recommendations to effectively organize activities for preschool children according to the STEAM orientation in Preschools.
\end{abstract}

Keywords: Organization, activities, STEAM, Kindergarten, Thai Nguyen province

\section{INTRODUCTION}

Children of preschool age include those aged 3 - 6 years old. At the age of 3 - 4 years old, the child's main activity is with the world of human-created objects. Therefore, children are very interested in participating in activities with things and it is through these activities that their thinking is that visual thinking of action will develop. At the same time, at the age of 3 , children began to appear independent aspirations, so they tend to imitate adults.With the above psychological characteristics of preschool children, if preschool teachers use educational organization methods Modernity will develop student psychology [1]. One of the modern approaches that can develop a student's psychology is STEAM. STEAM is an acronym with a combination of STEM and Art (Creative Arts). STEM is a special educational method that integrates elements of Science (Science), Technology (Technology), Engineering (Engineering) and Math (Mathematics). STEAM class is a classroom for kindergarten children. To absorb knowledge from scientific and artistic activities. This method of early education is considered to be an improved education strategy. The United States was the first country to universalize this modern preschool. The training program combines the disciplines of Science, Technology, Engineering, Mathematics and Arts. Since then, it helps to promote children's thinking in a comprehensive way and the creativity potentials within each child [2]. This method allows children to choose topics, discoverable content suitable to their interests and personal capacities that will attract children's excitement when participating in activities [3]. Children not only study the theory but also practice applying many skills in many fields in order to solve the problem according to their thinking. This approach links the learning in school with the real life of the child. STEAM method helps children to experience and practice with skills and knowledge that are very close to their lives. Through each project, children will create real and useful products in life, which will inspire children and love to go to school, love to explore and explore all issues in life. That is the goal that STEAM is always aiming for [4].

\section{METHODOLOGY AND RESULTS}

Kindergarten 19/5 Thai Nguyen City was established on May 19, 1980, the school is named Kindergarten 19/5 City according to Decision No. 144 / QD-UBND dated December 28, 2000 of the City People's Committee. Thai Nguyen. The school has a total area of $10,782.3 \mathrm{~m} 2$, and has one school site. The school has enough room blocks: Children group room, kindergarten class; administrative and administrative division; room for learning; Block of dining room and other functional room block works. The school has enough equipment to serve the work of child care and education [5].

Regarding the quality of child care and education: The school directed $100 \%$ of groups and classes to implement the preschool program, issued Circular 17/2009 / TT-BGDĐT dated July 25, 2009 and amended and supplemented. Some 
contents according to Circular 28/2016 / TT-BGDĐT dated December 30, 2016 are in accordance with the correct age, ensuring sufficient documents, materials, and tools to serve in the education of children [6].

In the 2019-2020 school year, the school has 92 officers, teachers and staff members, including: 03 administrators; 71 teachers; 18 employees. $100 \%$ of managers and teachers have professional training qualifications that meet the standards and above standards. Teachers' managers, staff in the school are always allowed to participate in fostering and fostering to improve their professional qualifications and skills; enjoy full benefits under the current policy regime; annually assessed and rated according to principal standards and evaluated and rated teachers according to preschool teachers' professional standards [3].

In the school year 2019 - 2020, the school has a total of 30 classes with 968 children.

Kindergartens include 6 classes, 196 children; Kindergarten 3-4 years old includes 8 classes with 211 children; Kindergarten 4-5 years old includes 7 classes with 265 children; Kindergarten class 5-6 years old with a total of 9 classes with 296 children [5].

The school's facilities are always invested with attention: 100\% Classes have full air conditioners, televisions, shelves, etc. for children to operate; Block of specialized rooms: English classrooms, dance rooms, computer rooms, gymnasiums, multi-purpose houses, kitchen rooms, etc. are fully invested in modern facilities and equipment; The school has a standard playground area, spacious, with many trees. Children's playground is arranged into many areas such as: physical development area, nature discovery area, countryside market experience area, baby's vegetable garden, etc. has created a green, beautiful pedagogical environment [6].

In the educational program, children are always discovered and experienced through many different activities such as doing a scientific experiment, discovering objects [3], learning the principles of objects, knowledge of the universe, and crystal, volcano, water source, etc. [7]. However, to organize STEAM activities in accordance with the process, the school has not implemented it [4].

The design process works in 4 steps: Part 1: Icebreaking: Is the activity that attracts the child's attention, helps the child to have a relaxed, happy spirit, to focus more on the upcoming lesson. Part 2: Raising a problem that stimulates children's curiosity [8]. Ask open-ended questions to help your child reveal inherent insights. Direct children to ask the questions "why?" Part 3: Experience: Create an environment where children participate, experience the activity by themselves. Children will satisfy themselves with the question "why?" through that experience. Conclusion: Explain the meaning and lessons behind each activity. The action plan is implemented by us with the following specific process [6]: 2.1. Activity goals

2.1.1. Knowledge: Consolidating knowledge for children about the air (air is around us but cannot be seen; air has no color, no smell, no taste and no certain shape); Children know what is repulsion of the air; Children understand the characteristics of air cannons and know how to make air cannons according to the teacher's instructions

2.1.2. Skills: Develop in children skills to observe, distinguish, compare, judge, reason, work in groups; Develop critical thinking skills for children.

2.1.3. Attitude: Children are excited and actively participating in activities; Children play in solidarity and self-correct; Educate children to be aware of protecting the fresh air.

2.1.4. Capacity development orientation: Capacity of cooperation, sharing, and communication; Ability to solve problems and create; Scientific research capacity.

2.1.5 Prepare for the activity: Colored paper, toilet paper core, tape, scissors (to shape air cannons, paper dolls), rubber balloons, pencils enough for you and your child.

2.2. Knowledge of the steam field in the subject

\begin{tabular}{|c|c|c|c|c|}
\hline $\begin{array}{l}\text { Science Knowledge } \\
\text { (S) }+ \text { Children know } \\
\text { what is repulsion of } \\
\text { the air, know the } \\
\text { benefits of air } \\
\text { repulsion (can } \\
\text { create wind, make } \\
\text { objects move); } \\
\text { understand the } \\
\text { working principle of } \\
\text { air cannons. }\end{array}$ & $\begin{array}{l}\text { Technology } \\
\text { Knowledge (T) }+ \\
\text { Make air cannons } \\
\text { that use the force of } \\
\text { the air to knock over } \\
\text { objects. }\end{array}$ & $\begin{array}{l}\text { Technical } \\
\text { Knowledge (E) + } \\
\text { Choosing the right } \\
\text { materials to make } \\
\text { air cannon paper } \\
\text { dolls. } \\
+ \text { Use the cards to } \\
\text { form the model of } \\
\text { dolls and air } \\
\text { cannons }\end{array}$ & $\begin{array}{l}\text { Mathematical } \\
\text { Knowledge (M) } \\
+ \text { Quantity of } \\
\text { materials needed } \\
\text { to make air } \\
\text { cannons; } \\
\text { number of } \\
\text { objects spilled } \\
\text { by air cannons. } \\
+ \text { Consolidate } \\
\text { some math }\end{array}$ & $\begin{array}{l}\text { Art knowledge (A) } \\
+ \text { Modeling paper } \\
\text { dolls and air } \\
\text { cannons } \\
+ \text { Decorate models } \\
\text { of paper dolls and } \\
\text { air cannons }\end{array}$ \\
\hline
\end{tabular}




\begin{tabular}{|l|l|l|l|}
\hline & $\begin{array}{l}\text { + Combined use of } \\
\text { balloons and air } \\
\text { cannon model to } \\
\text { create air thrust. }\end{array}$ & $\begin{array}{l}\text { symbols: bigger, } \\
\text { smaller; top } \\
\text { bottom; the forth } \\
\text { and the } \\
\text { backward. }\end{array}$ \\
\hline
\end{tabular}

\subsection{Organizing activities}

2.4.1. Warm-up: She and the child share their understanding of the atmosphere.

+ Although we cannot see with our eyes, there is always air around us.

The air is colorless, odorless, tasteless, and has no certain shape.

+ The air has thrust, if affected, it can create wind, making objects move.

+ We will test the thrust of the air by trying to make cannons using the power of the air.

2.4. Activity 3: Share the principle of air cannons

Teacher's activities
Inside the air cannon she made had a certain amount of air. As she pulls the
rubber balloon backwards, there will be some air inside the rubber balloon.
Now, if you release the rubber balloon, the air in the balloon will be pushed
forward and push the air inside the cannon out, the affected air will create
wind blowing into the paper doll, making the doll. a spilled paper calf. Let us
count with you how many paper dolls have been spilled by your air cannon.

Children count the spilled paper dolls.

\subsection{Practicing activities, expanding}

\begin{tabular}{|l|l|}
\hline \multicolumn{1}{|c|}{ Teacher's activities } & Children's Activities \\
\hline - Do we want to make and test air cannons like you? & -The child responded to her \\
- She divided the children into 3 groups, giving each group of children a set & suggestion \\
of tools to make air cannons. She instructs children how to make air cannons. & -Children follow her \\
- Organize a competition for children to see which team's air cannons can & instructions. \\
spill more paper dolls. & $\begin{array}{l}\text {-Children perform, compete with } \\
\text { each other. }\end{array}$ \\
\hline
\end{tabular}

2.6. Guiding to self-study, consolidate knowledge, practice skills

\begin{tabular}{|l|l|}
\hline \multicolumn{1}{|c|}{ Teacher's activities } & Children's Activities \\
\hline $\begin{array}{l}\text { - She repeated how to make air cannons and how air cannons work. } \\
\text { - She tells children to go home to learn about energy use tools } \\
\text { of the atmosphere, the next day to class share with her and friends. }\end{array}$ & -Children listen \\
\hline
\end{tabular}

Above is a plan we have instructed teachers to build. For the finalization plan, we have consulted Dr. NMU University of Education - Thai Nguyen University. After editing according to expert opinion, we organize activities on 15 preschool children. To evaluate the effectiveness of the STEAM-oriented organization compared to the traditional organization, we conducted observations, using the following case study exercises:

\begin{tabular}{|c|c|c|c|c|c|c|}
\hline \multirow[t]{2}{*}{ Levels } & \multicolumn{2}{|l|}{ Awareness } & \multicolumn{2}{|l|}{ attitude } & \multicolumn{2}{|l|}{ attitude } \\
\hline & $\begin{array}{l}\text { Organized in } \\
\text { the usual form }\end{array}$ & $\begin{array}{l}\text { STEAM } \\
\text { oriented } \\
\text { organization }\end{array}$ & $\begin{array}{l}\text { Organized in } \\
\text { the usual form }\end{array}$ & $\begin{array}{l}\text { STEAM } \\
\text { oriented } \\
\text { organization }\end{array}$ & $\begin{array}{l}\text { Organized in } \\
\text { the usual } \\
\text { form }\end{array}$ & $\begin{array}{l}\text { STEAM } \\
\text { oriented } \\
\text { organizatio } \\
\mathrm{n}\end{array}$ \\
\hline Good 1 & 7 & 20 & 9 & 22 & 6 & 19 \\
\hline $\begin{array}{l}\text { Fairly good } \\
2\end{array}$ & 18 & 5 & 15 & 3 & 13 & 5 \\
\hline \multirow[t]{2}{*}{ Not good 3} & 0 & 0 & 1 & 0 & 6 & 1 \\
\hline & \multicolumn{2}{|l|}{$\mathrm{P}=0.00022534$} & \multicolumn{2}{|l|}{$\mathrm{P}=0.0001521$} & \multicolumn{2}{|c|}{$\mathrm{P}=0.00023603$} \\
\hline
\end{tabular}


We use the Chi-square test to find the difference between the results achieved when teaching in a normal form and the STEAM-oriented organization on the following aspects: perception., attitude, behavior. The results achieved in the above table are:

Awareness: $\mathrm{P}=0.00022534$

Attitude: $\mathrm{P}=0.0001521$

Behavior: $\mathrm{P}=0.00023603$

To confirm whether that value is significant or not, we compare the result of $\mathrm{P}$ value with check the significance of mean difference to draw a conclusion.

Checklist of mean difference

\begin{tabular}{|l|l|}
\hline Results & Correlation between group composition and outcome \\
\hline $\mathrm{P}<0,001$ & Significant correlation (The data is not likely to happen at random) \\
\hline $\mathrm{P}>0,001$ & Correlation is not significant (Possible random data) \\
\hline
\end{tabular}

Comparing with the $\mathrm{P}$ value based on the above criteria table shows that: The $\mathrm{P}$ value in the test when squaring the perception, attitude, and behavior are $<0.001$. Thus, the above result is significant, the difference is not likely to happen randomly [9]. This shows that the impact has brought results, the STEAM-oriented organization brings more efficiency, changes in a positive direction in perception, attitudes, and behaviors compared to ordinary organizations. .

Thus, the STEAM-oriented organization will develop the child's psychology on all three aspects: perception, attitude, and behavior compared to the normal form of organization [10].

\section{CONCLUSIONS AND RECOMMENDATIONS}

STEAM is a new educational model that can be effectively applied in public preschools in Vietnam. However, this is a new educational orientation, public preschools have not been implemented regularly, so teachers do not have the capacity to design and implement activities. The biggest difficulty when applying the STEAM educational model in public preschools is that the curriculum framework of the grade levels does not have much experience, there are not many scientific activities, etc. for children to carry out. STEAM activities; teachers have not been trained in the capacity to organize STEAM activities; infrastructure conditions are not rich, do not meet requirements when organizing activities.

For successful STEAM-oriented public preschool activities, we have the following recommendations: Strengthening the thematic content related to STEAM-oriented children's activities in the nomination program preschool education personnel; additional topics for fostering STEAm educational capacity in regular training programs for teachers in public preschools; open training courses to help teachers actively design STEAM activities in the program. Preschool teachers actively collect safe waste materials to perform STEAM activities, create conditions for children to participate in activities, develop comprehensively the capacity of preschool children.

\section{REFERENCES}

[1] Brown, J. (2012). The current status of STEM education research. Journal of STEM Education: Innovations and Research, 13(5).

[2] Brown, R., Brown, J., Reardon, K., \& Merrill, C. (2011). Understanding STEM: current perceptions. Technology and Engineering Teacher, 70(6), 5.

[3] YILDIRIM, B., \& Altun, Y. (2015). STEM eğitim ve mühendislik uygulamalarının fen bilgisi laboratuar dersindeki etkilerinin incelenmesi. El-Cezeri Journal of Science and Engineering, 2(2).

[4] Barnes, J., FakhrHosseini, M. S., Vasey, E., Duford, Z., \& Jeon, M. (2017, September). Robot theater with children for STEAM education. In Proceedings of the Human Factors and Ergonomics Society Annual Meeting (Vol. 61, No. 1, pp. 875-879). Sage CA: Los Angeles, CA: SAGE Publications.

[5] Jamil, F. M., Linder, S. M., \& Stegelin, D. A. (2018). Early childhood teacher beliefs about STEAM education after a professional development conference. Early Childhood Education Journal, 46(4), 409417. 
[6] Jin, Y. G., Chong, L. M., \& Cho, H. K. (2012, November). Designing a robotics-enhanced learning content for STEAM education. In 2012 9th international conference on ubiquitous robots and ambient intelligence (URAI) (pp. 433-436). IEEE.

[7] Sau, N. T. U., Phuong, C. N. L., \& Hoi, H. T. (2020). Benefits of Building Child-centered Learning Environment in Kindergarten. Universal Journal of Educational Research, 8(12), 6765-6769.

[8] Shatunova, O., Anisimova, T., Sabirova, F., \& Kalimullina, O. (2019). STEAM as an Innovative Educational Technology. Journal of Social Studies Education Research, 10(2), 131-144.

[9] Dejarnette, N. K. (2018). Implementing STEAM in the Early Childhood Classroom. European Journal of STEM Education, 3(3), 18.

[10] Barnes, J., FakhrHosseini, S. M., Vasey, E., Park, C. H., \& Jeon, M. (2020). Child-robot theater: Engaging elementary students in informal STEAM education using robots. IEEE Pervasive Computing, 19(1), 2231. 